\title{
The Aelurillina Simon, 1901 (Aranei: Salticidae) of Iran: a check-list and three new species of Aelurillus Simon, 1884 and Proszynskiana Logunov, 1996
}

\section{Aelurillina Simon, 1901 (Aranei: Salticidae) Ирана: список видов и три новых вида Aelurillus Simon, 1884 и Proszynskiana Logunov, 1996}

\author{
Galina N. Azarkina ${ }^{*}$, Alireza Zamani ${ }^{2}$ \\ Г.Н. Азаркина ${ }^{1 *}$, А. Замани ${ }^{2}$
}

\begin{abstract}
${ }^{1}$ The Laboratory of Systematics of Invertebrate Animals, The Institute of Systematics and Ecology of Animals, Siberian Branch Russian Academy of Sciences, Frunze Street 11, Novosibirsk 630091, Russia. E-mail: urmakuz@gmail.com

1 Лаборатория систематики беспозвоночных животных, Институт систематики и экологии животных СО РАН, ул. Фрунзе 11 , Новосибирск 630091 Россия.

${ }^{2}$ Zoological Museum, Department of Biology, FI-20014 University of Turku, Finland. E-mail: zamani.alireza5@gmail.com

*Corresponding author
\end{abstract}

KEY WORDS: Aelurillus, Araneae, jumping spiders, Lut Desert, new species, Proszynskiana, spiders.

КЛЮЧЕВЫЕ СЛОВА: Aelurillus, Araneae, новые виды, пауки, пауки-скакунчики, пустыня Лут, Proszynskiana.

ABSTRACT. A complete check-list of the subtribe Aelurillina Simon, 1901 of Iran is provided. A new species of Aelurillus Simon, 1884 and two new species of Proszynskiana Logunov, 1996 are described: viz., A. westi sp.n. ( $\sigma^{7}$, Isfahan Province, central Iran), $P$. izadii sp.n. ( $\sigma^{\top}+$, Lut Desert, Kerman Province, southeastern Iran) and $P$. logunovi sp.n. ( $\sigma^{\top}$, Kerman Province, south-eastern Iran). The currently known records of the Iranian Aelurillina are mapped, and complete reference lists for each species are also provided.

How to cite this article: Azarkina G.N., Zamani A. 2019. The Aelurillina Simon, 1901 (Aranei: Salticidae) of Iran: a check-list and three new species of Aelurillus Simon, 1884 and Proszynskiana Logunov, 1996 // Arthropoda Selecta. Vol.28. No.1. P.83-97. doi: 10.15298/ arthsel. 28.1.07

РЕЗЮМЕ. Приведён полный чек-лист подтрибы Aelurillina Simon, 1901 Ирана. Описаны один новый вид Aelurillus Simon, 1884 и два новых вида Proszynskiana Logunov, 1996: а именно, A. westi sp.n. ( $\sigma^{7}$, остан Исфахан, центральный Иран), P. izadii sp.n. ( $\bigcirc^{7}$, пустыня Лут, остан Керман, ого-восточный Иран) и P. logunovi sp.n. ( ${ }^{7}$, остан Керман, юго-восточный Иран). Прокартированы все известные находки иранских Aelurillina и также приведены полные списки литературных ссылок для каждого вида.

\section{Introduction}

Based on Maddison [2015] and the recent synonymies proposed by Logunov \& Azarkina [2018], the subtribe Aelurillina Simon, 1901 (Aelurillini: Salticoi- da: Salticidae) currently contains nine genera, primarily known from the Old World, with the exception of Phlegra hentzi Marx, 1890 from Canada and the USA [WSC, 2018].

The first spider collection from Iran was assembled by Keyserling \& Bienert in 1859 [Mozaffarian, Marusik, 2001]. Roewer [1955] described a new monotypic aelurilline genus Hemsenattus, with its generotype being Hemsenattus iranus Roewer, 1955. Later, this genus was synonymized with Aelurillus Simon, 1884 [Prószyński, 1966], and then Aelurillus iranus was synonymized with $A$. concolor Kulczyński, 1901 (see Nenilin, 1984). A number of papers on the Iranian spider fauna started to appear after Yu.M. Marusik's field trip to Iran in 2000, leading to the publication of the first check-list of Iranian spiders [Mozaffarian, Marusik, 2001] and four papers based on Marusik's material that included data on the Aelurillina [Azarkina, 2002, 2004; Logunov, 2001; Logunov et al., 2002]. Later, twelve more papers containing information on the Aelurillina have been published [Azarkina, Mirshamsi, 2014; Ghahari, Marusik, 2009; Ghahari, Tabari, 2012; Kashefi et al., 2013; Logunov, 2010, 2013; Logunov, Koponen, 2002; Logunov et al., 2007; Mirshamsi et al., 2013; Sadeghi et al., 2016; Zamani, Mozaffarian, 2017; Zamani et al., 2017, 2018b]. Currently, the salticid fauna of Iran includes five genera of the Aelurillina: viz., Aelurillus (five species), Langona Simon, 1901 (four species), Phlegra Simon, 1876 (five species), Rafalus Prószyński, 1999 (one species) and Stenaelurillus Simon, 1886 (one species) [Zamani et al., 2018a,b].

The aims of this paper are: (1) to describe a new Aelurillus species, A. westi sp.n.; (2) to describe two 
new Proszynskiana species, P. izadii sp.n. and P. logunovi sp.n.; and (3) to map the distribution of all the Aelurillina species known from Iran to date.

\section{Material and methods}

The studied specimens are shared between the following museums (curators in parentheses): ISEA - Institute of Systematics and Ecology of Animals, Novosibirsk, Russia (G.N. Azarkina); MMUE — The Manchester Museum, University of Manchester, UK (D.V. Logunov); ZISP - Zoological Institute of the Russian Academy of Sciences, St. Petersburg, Russia (V.A. Krivokhatsky).

A total of 19 specimens belonging to three genera and five species has been examined. Specimens were studied in ethanol and their coloration refers to that of the preserved specimens. All drawings were made with the aid of a reticular eyepiece attached to a MBS-10 stereomicroscope. The epigynes were detached and macerated in $20 \% \mathrm{KOH}$ solution overnight. Photographs were taken by means of a Canon EOD 5500D attached to Zeiss Stemi 2000-C. Focal planes of single image stacks were combined using the Helicon Focus 6.3 software at the Institute of Systematics and Ecology of Animals. All drawings were edited and assembled in Adobe Photoshop CS5. Photos of living specimens were taken with a Canon PowerShot G15 camera by AZ.

The terminology follows Azarkina et al. [2018] and Logunov \& Azarkina [2018]. Abbreviations used in the text are as follows: ALE - anterior lateral eyes, AME - anterior median eyes, ap - apical, d - dorsal, EO - embolic division, EP - epigynal pocket, EW - epigynal wings, $\mathrm{Fm}$ - femur, ID - insemination duct, Mt - metatarsus, pr - prolateral, PLE - posterior lateral eyes, PS - primary spermatheca, Pt - patella, RTA - retrolateral tibial apophysis, SR - salticid radix, TA - terminal apophysis, $\mathrm{Tb}$ - tibia, $\mathrm{rt}$ - retrolateral, $\mathrm{v}$ - ventral. All measurements are in $\mathrm{mm}$. For leg spination the system adopted is that used by Ono [1988].

\section{Taxonomy}

\section{Genus Aelurillus Simon, 1884}

At present, the genus Aelurillus includes 72 valid species (including two subspecies), of which five species have been recorded from Iran, with three of them being considered regional endemics [WSC, 2018]. The new species described below is the sixth Aelurillus species and the fourth endemic known from Iran. The territory of neighbouring Turkmenistan is known to contain approximately the same number of Aelurillus species (7), but a less number of the endemics (2). As the territory of Iran is about three times larger than that of Turkmenistan and has a much more diverse relief, it is likely that there are more unrecorded or new to science species of Aelurillus in the Iranian fauna.

The genus Aelurillus, as well as other Aelurillina, is a difficult taxon to work with because the embolic division (EO) in the male palps is hidden inside the cymbial pocket. The aelurilline embolic division is rather complex, consisting of two parts: the 'principal sclerite' that is homologous to the true embolus and the 'foot sclerite' that seems to be homologous to the tegular apophysis (see Logunov [1996] for further details). According to Azarkina [2002], the EO of Aelurillus consists of the following parts: the embolus (= the principal sclerite), the terminal apophysis (= the foot sclerite) and the membrane connecting them. Species identification in some Aelurillus is possible on the basis of the males only, due to a high variation of the female copulatory organs (e.g., see figs 73-81 in Azarkina \& Logunov, 2006].

Aelurillus, with a few exceptions, has a primarily Palaearctic distribution, with two modern centres of species diversity in the Mediterranean and Middle Asia, both being parts of the Ancient Mediterranean (sensu Kryzhanovsky [2002]).

Aelurillus westi sp.n.

Figs 1-9, 12-13, 16-19, 21-23, Map.

TYPES. HоLотуPE $O^{7}$ (MMUE, G7613.1) from Iran, Isfahan Province, Qamsar and Barzok Protected Area, c. $55 \mathrm{~km} \mathrm{SW}$ of

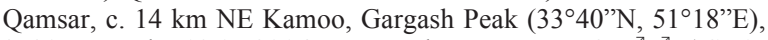
$3530 \mathrm{~m}$ a.s.l., 19.05.2016, P. Ponel. Paratypes: 2 oे $\sigma^{7}$ (ISEA, 001.8145), $8 \mathrm{O}^{7} \sigma^{7}$ (MMUE, G7613.2), together with the holotype.

COMPARATIVE MATERIAL on Aelurillus v-insignitus (Clerck, 1758): TURKEY: $1 O^{7}$ (ISEA), Artv n Province, Hopa (c. $\left.41^{\circ} 23^{\prime} \mathrm{N}, 41^{\circ} 25^{\prime} \mathrm{E}\right), 17.05 .1997, \mathrm{~V}$. Bryja. - AZERBAIJAN: $10^{\circ}$ (ISEA), Gobustan Rayon, Gobustan [=Qobustan] vicinity (c. $40^{\circ} 04^{\prime} \mathrm{N}, 49^{\circ} 23^{\prime} \mathrm{E}$ ), pitfall traps, 3.06.2016, T.V. Nurueva. TURKMENISTAN: $2 O^{7} \sigma^{\top}$ (ISEA), Aşgabat [=Ashkhabat], Bekrewe [=Bikrowa] (c. $\left.37^{\circ} 55^{\prime} \mathrm{N}, 58^{\circ} 17^{\prime} \mathrm{E}\right)$, adyr, 14.04.1991, V.V. Duba-

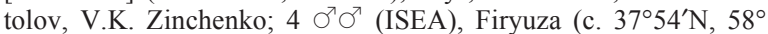
$05^{\prime} \mathrm{E}$ ), grassy slopes, rocks, 2.04.1991, V.V. Dubatolov.

ETYMOLOGY. This species is dedicated to the Canadian arachnologist, Mr Rick C. West (British Columbia, Canada), who inspired the second author in his childhood to become an arachnologist.

DIAGNOSIS. By body coloration and conformation of the copulatory organs, $A$. westi sp.n. is similar to the Palaearctic $A$. v-insignitus, but differs from it in the coloration of clypeus and cheeks, which are covered with long white hairs in $A$. westi sp.n. (Figs 21-22) but with short white hairs in $A$. $v$-insignitus (Figs 24-25). The eye field of $A$. westi sp.n. has a pattern consisting of five white longitudinal streaks and four brownish longitudinal lines in between them, with the entire pattern resembling the letter ' $W$ ' (Figs 21-23), whereas the eye field pattern in A. v-insignitus consists of two white bent streaks and brown line in between them, resembling two white letters ' $V$ ' nested in each other (Figs 2426). Aelurillus westi sp.n. has Tb I densely covered with whitish brownish hairs pro-, retrolaterally and ventrally, metatarsi and tarsi densely covered with dark brown hairs (Figs 18-19), whereas A. v-insignitus lacks such hairs (Fig. 20). Aelurillus westi sp.n. has a broad ventral tibial apophysis, with a bulge forming obtuse angle on its dorsal side (Figs 8,13, arrowed), whereas A. v-insignitus has a narrow triangle-shaped ventral tibial apophysis (Fig. 15 and figs 27-28, 40, 43 in Żabka [1997]). Aelurillus westi sp.n. also differs from $A$. $v$-insignitus in the conformation of EO: the embolus is slightly bent ventrad in $A$. west $i$ sp.n. (Figs 7-9) (vs. straight in A. v-insignitus; Figs 10-11); the TA tip round, softly contoured and barely coloured (Figs 7-9) (vs. the sharpened TA tip in A. v-insignitus; Figs 10-11).

DESCRIPTION. MaLe (holotype): Carapace 2.85 long, 2.00 wide, 1.60 high at PLE. Ocular area 1.10 long, 1.40 wide anteriorly and 1.50 wide posteriorly. Diameter of AME 0.45. Abdomen 2.40 long, 2.10 wide. Cheliceral length 0.60. Clypeal height 0.30 . Length of leg segments: I $1.30+0.90+$ $0.90+0.65+0.60(4.35) ;$ II $1.30+0.80+0.80+0.60+$ 0.55 (4.05); III $1.80+0.90+1.20+0.60+0.60(5.10)$; IV $1.75+0.90+1.00+1.30+0.60$ (5.55). Leg spination: I: Fm d 1-1-5; Pt pr and rt 1; Tb d 1-0, pr 1-1-1, rt 1-1-0, v 2-22 ap; Mt pr and rt 1-1 ap, v 2-2 ap. II: Fm d 1-2-5; Pt pr 

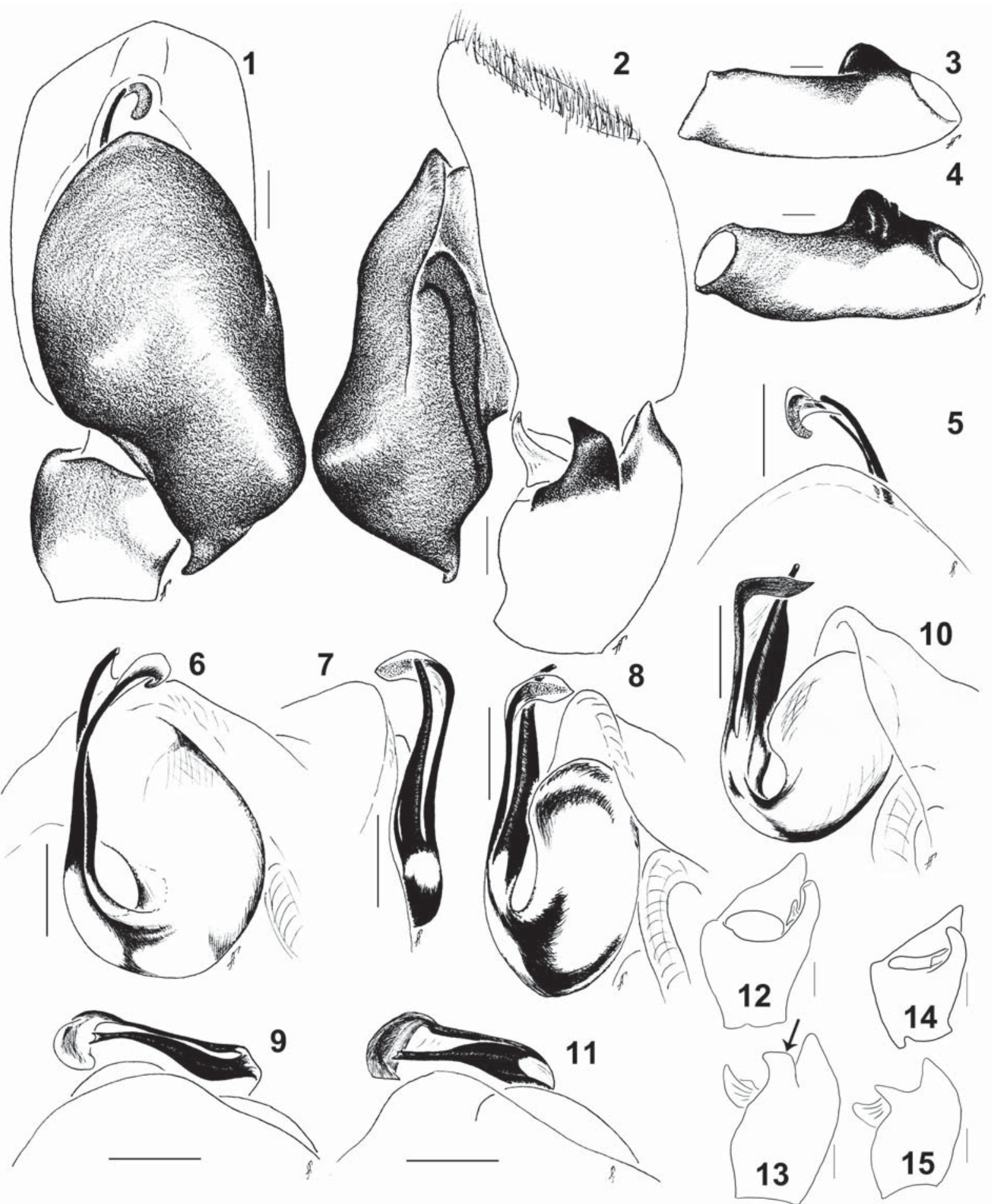

Figs 1-15. Male copulatory organs of Aelurillus westi sp.n. $(1-9,12,13)$ and A. v-insignitus (Clerck, 1758) $(10,11,14,15): 1$ - left palp, ventral view, holotype; 2 - ditto, retrolateral view; 3 - palpal femur, retrolateral view, the holotype; 4 - ditto, ventro-retrolateral view; 5 - right EO, ventral view, the paratype (MMUE, G7613.2); 6 - ditto, dorsal view; 7 - ditto, prolateral view; 8,10 - ditto, retrolateral view; 9, 11 - ditto, ventro-prolatero-apical view; 12, 14 - left palpal tibia, ventral view; 13, 15 - ditto, retrolateral view. Scale bars $=0.1 \mathrm{~mm}$.

Рис. 1-15. Копулятивные органы самцов Aelurillus westi sp.n. $(1-9,12,13)$ и A. v-insignitus (Clerck, 1758) $(10,11,14,15): 1-$ левая пальпа, вентрально, голотип; 2 - то же, ретролатерально; 3 - бедро пальпы, ретролатерально, голотип; 4 - то же, вентроретролатерально; 5 - ЕО правой пальпы, вентрально, паратип (MMUE, G7613.2); 6 - то же, дорсально; 7 — то же, пролатерально; 8, 10 - то же, ретролатерально; 9, 11 - то же, вентро-пролатеро-апикально; 12,14 - бедро левой пальпы, вентрально; 13,15 то же, ретролатерально. Масштаб 0,1 мм. 

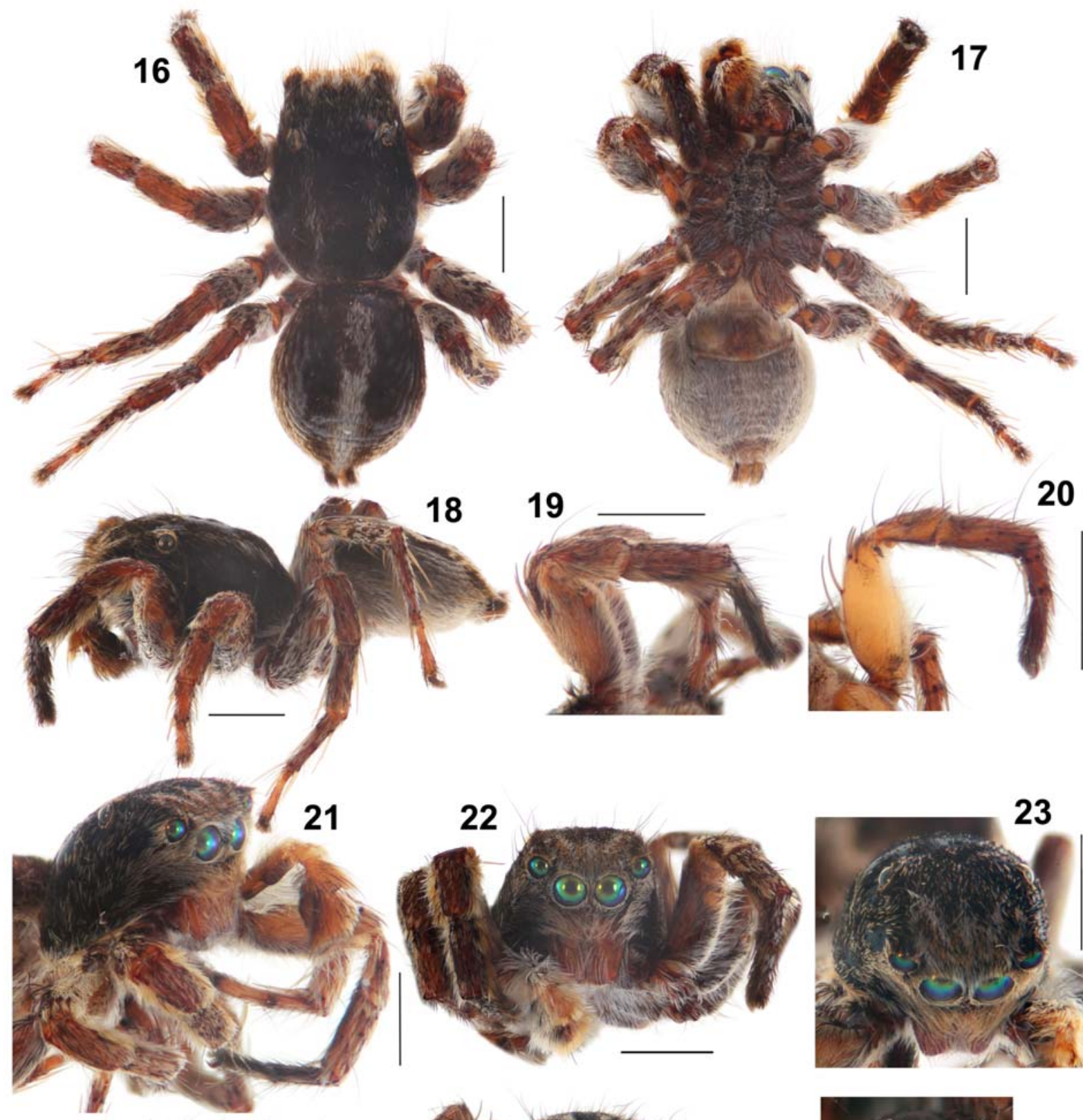

19
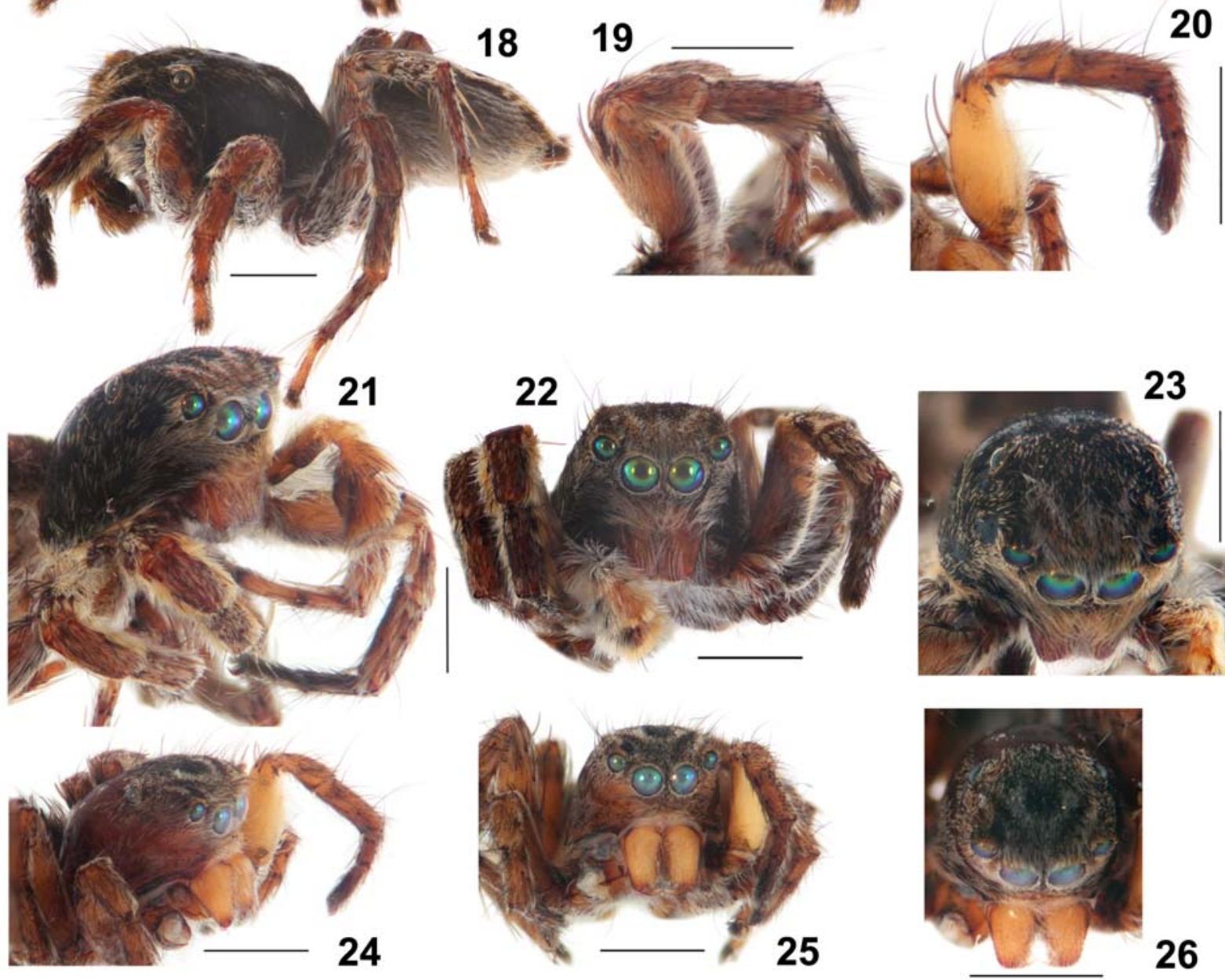

26

Figs 16-26. General appearance of Aelurillus westi sp.n. (16-19, 21-23) and A. v-insignitus (Clerck, 1758) (specimen from Azerbaijan; 20, 24-26): 16 - A. westi sp.n., dorsal view, holotype; 17 - ditto, ventral view; 18 - ditto, lateral view; 19, 20 - left leg I, prolateral view; 21, 24 - latero-frontal view, paratype (MMUE, G7613.2); 22, 25 - ditto, frontal view; 23, 26 - ditto, dorso-frontal view. Scale bars $=1 \mathrm{~mm}$.

Рис. 16-26. Внешний вид Aelurillus westi sp.n. (16-19, 21-23) и A. v-insignitus (Clerck, 1758) (экземпляр из Азербайджана; 20, 24-26): 16 — дорсально, голотип; 17 — то же, вентрально; 18 — то же, латерально; 19, 20 - левая нога I, пролатерально; 21, 24 латеро-фронтально, паратип (MMUE, G7613.2); 22, 25 - то же, фронтально; 23, 26 - то же, дорсо-фронтально. Масштаб 1 мм. 


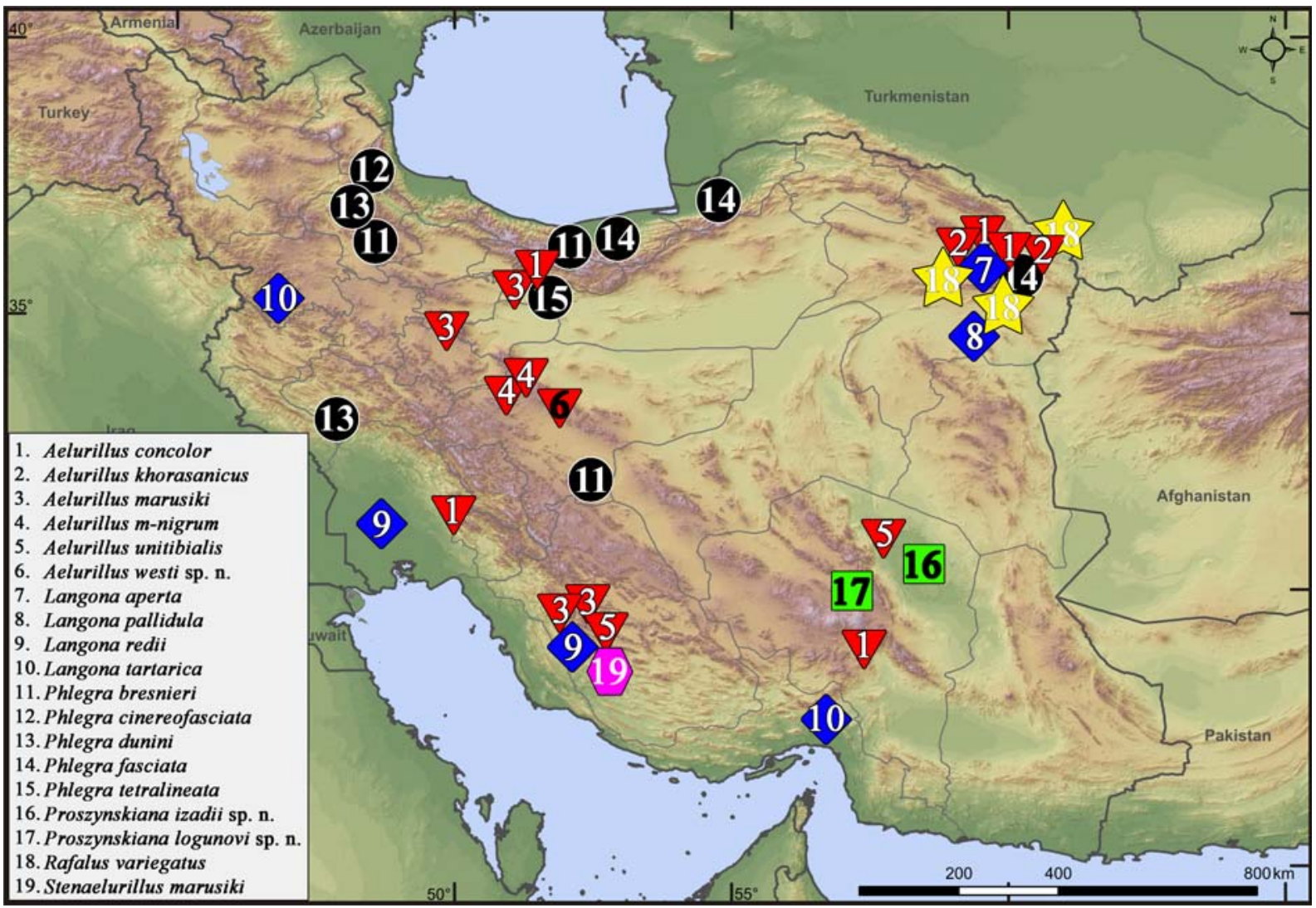

Map. Collecting localities of the Aelurillina of Iran: black numbers — original data; white numbers — literature derived data.

Карта. Точки сборов Aelurillina Ирана: черные номера - оригинальные данные; белые номера - литературные данные.

and rt 1; Tb d 1-0, pr 1-1-1, rt 1-1-0, v 1-1-2 ap; Mt pr and rt 1-1ap, v 2-2 ap. III: Fm d 1-3-5; Pt pr and rt 1; Tb d $1-0-0$, pr and rt 1-1-1-1, v 1-0-2 ap; Mt d 1-1-0, pr and rt 1-0-2 ap, v 1-1-2 ap. IV: Fm d 1-1-5; Pt pr and rt 1; Tb d $1-0-0$, pr and rt $1-1-1-1$, v $1-0-2$ ap; Mt d $1-1-0$, pr $1-1-$ 2 ap, rt 1-0-2 ap, v 1-1-2 ap. Coloration (in alcohol). Carapace dark brown, almost black, dorsally with two white longitudinal bands, marginally with white hairs (Fig. 16). Eye field with white and brownish scales forming a W pattern (Figs 21-23). Sternum dark brown, almost black, covered with white scales (Fig. 17). Labium dark brown, endites brown, pale apically. Cheeks dark brown, covered with yellowish white hairs. Clypeus yellow-brown, covered with yellowish white long hairs (Figs 21-22). Chelicerae brown. Abdomen grey-yellow-brown ventrally, covered with white scales; dark brown dorsally, medially with white longitudinal band (Fig. 16). Book-lungs yellow. Genital area brown. Anterior spinnerets brown, posterior dark brown. All legs dark brown, with light brown patches and bands. Tibiae I ventrally dark brown, metatarsi and tarsi I dark brown, covered with dense dark brown hairs (Figs 18-19, 21-22). Palpal femur dark brown, patella, tibia and cymbium yellow-brown, covered with dense long yellow-white hairs and dark brown sparse bristles. Palpal organs as in Figs 1-9: palpal tibia with three (two chitinized and one membranous) processes (Figs 12-13); femur with a prolatero-ventral bulge (Figs 3-4); embolus and TA bending ventrad (Figs 7-9); TA tip round, twisting in prolatero-ventral direction (Figs 5-6, 9).

Female unknown.

DISTRIBUTION. The type locality only (Map).

\section{Genus Proszynskiana Logunov, 1996}

To date, the genus Proszynskiana has included five species described and known from both sexes from Middle Asia, except for $P$. aeluriforma Logunov et Rakov, 1998 described from the male only [WSC, 2018]. However, the occurrence of representatives of this genus in Iran was already predicted [Logunov, 1996, 2010; Logunov et al., 2002], and the present study just confirms this.

Proszynskiana is diagnosed by the characters that are unique among other Aelurillina and even the entire family Salticidae (see Logunov [1996a]): ALE only slightly smaller than AME (Figs 40-45 and fig. 13 in Logunov [1996a]); chelicerae possess a massive white protuberance (arrowed in Fig. 48 and arrowed in fig. 30 in Logunov [1996a]); tarsi of all legs without pulvillae, only hard bristles present (arrowed in Figs 46-47, 49-50 and in figs. 15, 22-23 in Logunov [1996a]); cymbial pocket open (Figs 27, 57 and fig. 3 in Logunov [1996a]); and the funnel-shaped spermathecae (Fig. 65 and figs 37, 45, 52 and 60 in Logunov [1996a]). Both newly described species — Proszynskiana izadii sp.n. and $P$. logunovi sp.n. - possess all the unique diagnostic characters of Proszynskiana.

\section{Proszynskiana izadii sp.n.}

Figs 27-46, 53-54, Map.

TYPES. HolotyPe $\sigma^{7}$ (MMUE, G7613.6) from Iran, Kerman Province, Lut Desert, Rig-e Setareh $\left(30^{\circ} 15^{\prime} 26.5^{\prime \prime} \mathrm{N}, 58^{\circ} 42^{\prime} 56.6^{\prime \prime} \mathrm{E}\right)$, 


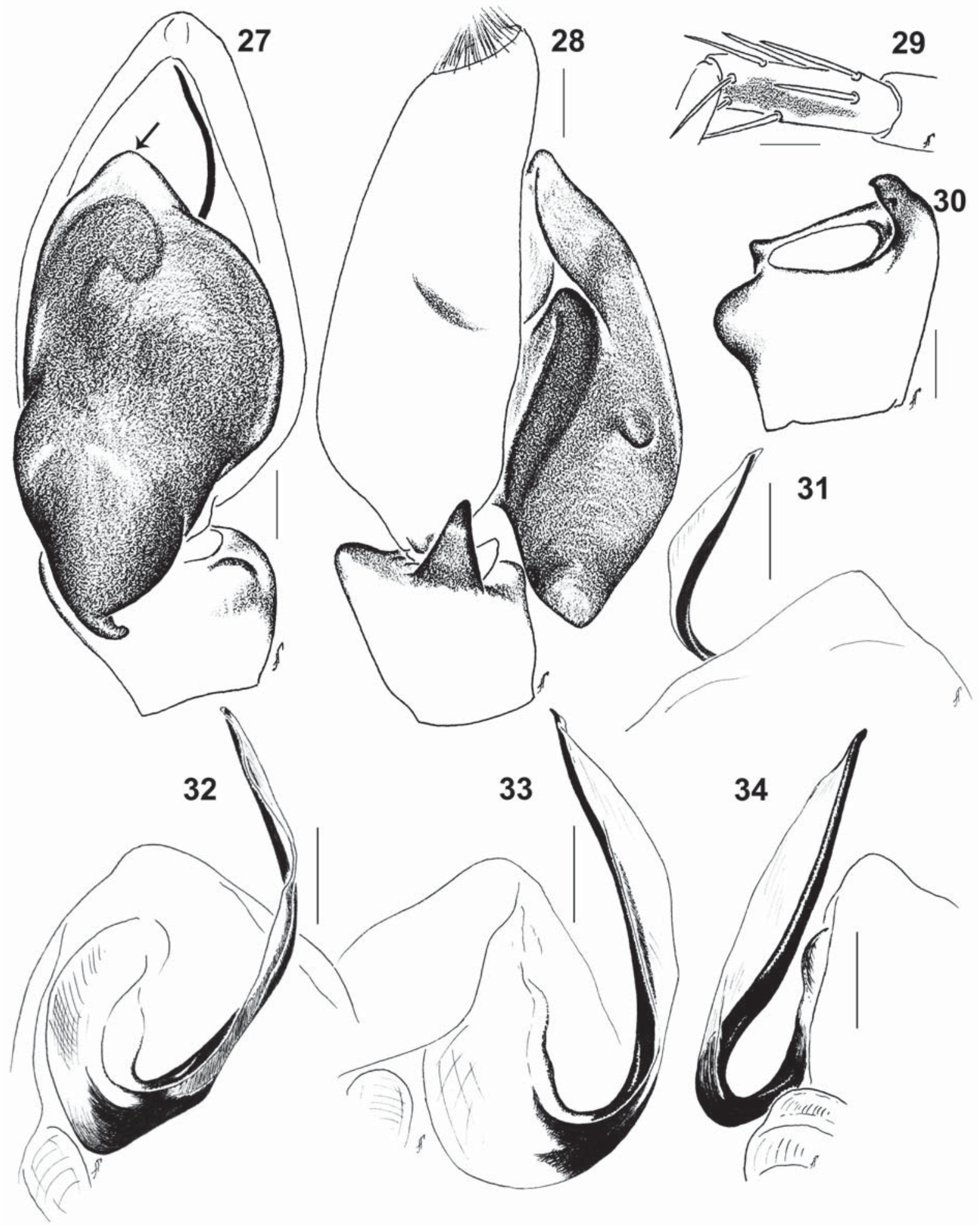

Figs 27-34. Male copulatory organs of the holotype Proszynskiana izadii sp.n.: 27 - right palp, ventral view; 28 - ditto, retrolateral view; 29 - tibia of leg I, prolatero-ventral view; 30 - left palpal tibia, ventral view; 31 - left EO, ventral view; 32 - ditto, dorsal view; 33 - ditto, retrolateral view; 34 - ditto, prolateral view. Scale bars $=0.1 \mathrm{~mm}$.

Рис. 27-34. Копулятивные органы голотипа самца Proszynskiana izadii sp.n.: 27 - правая пальпа, вентрально; 28 - то же, ретролатерально; 29 - голень I пары ног, пролатеро-вентрально; 30 - голень левой пальпы, вентрально; 31 - ЕО левой пальпы, вентрально; 32 - то же, дорсально; 33 - то же, ретролатерально; 34 - то же, пролатерально. Масштаб 0,1 мм. 

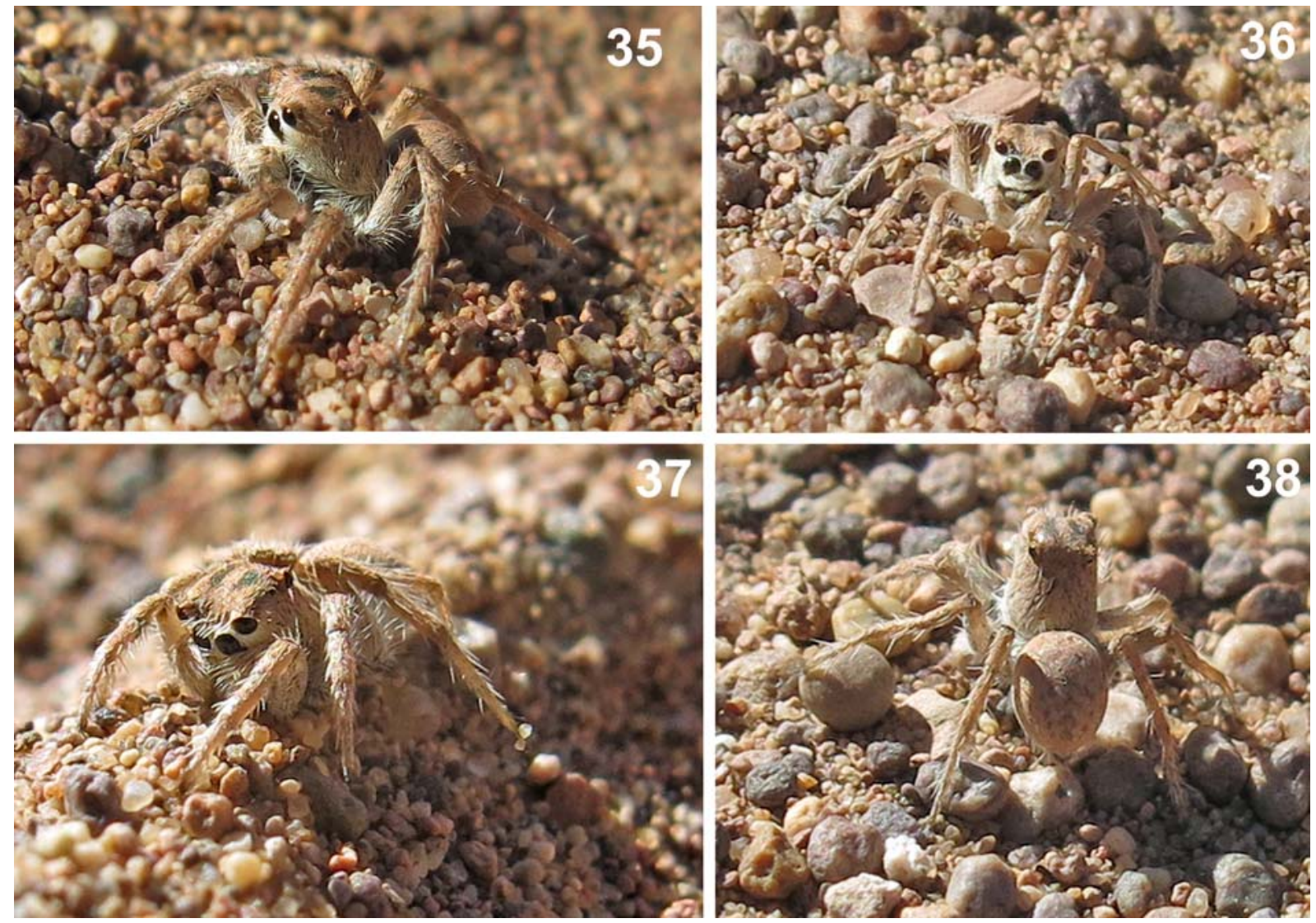

Figs 35-38. Proszynskiana izadii sp.n., immature specimen from the type locality.

Рис. 35-38. Proszynskiana izadii sp.n., неполовозрелый экземпляр из типового местообитания.

252 m a.s.1., July 2013, B. Izadi. Paratype: 1 ( (MMUE, G7613.7), together with the holotype, the epigyne is lost.

ETYMOLOGY. This species in named after Mr Bahman Izadi (Tehran, Iran), who collected the type series, in recognition of his efforts towards the understanding of the natural history of Lut Desert.

DIAGNOSIS. By the RTA conformation, $P$. izadii sp.n. is most similar to P. iranica Logunov, 1996 and P. zonshteini Logunov, 1996 from Turkmenistan but differ as follows: the dorsal tibial apophysis small, pointed dorso-apicad (cf. Fig. 28, and figs 41 and 54 in Logunov [1996a], respectively); yet, in P. starobogatovi Logunov, 1996 dorsal TA small and pointed ventrad (cf. fig. 48 in Logunov [1996a]) and in $P$. aeluriforma the dorsal TA is almost indistinguishable (cf. fig. 52 in Logunov \& Rakov [1998]). By the structure of EO (viz., the terminal apophysis membranous and poorly marked), the new species is most similar to $P$. logunovi sp.n., from which it differs in the EO shape (cf. Figs 31-34 and 60-63); all other Proszynskiana species have the heavy sclerotized terminal apophysis. From all the Proszynskiana species, $P$. izadii sp.n. also differs in having an apical bump on SR (arrowed in Fig. 27).

DESCRIPTION. MALE (holotype): Carapace 2.60 long, 1.80 wide, 1.50 high at PLE. Ocular area 1.20 long, 1.35 wide anteriorly and 1.25 wide posteriorly. Diameter of AME 0.45 . Abdomen 2.00 long, 1.50 wide. Cheliceral length 0.60 . Clypeal height 0.20 . Length of leg segments: I $1.50+0.60+$ $1.00+0.70+0.65(4.45) ;$ II $1.45+0.80+1.00+0.80+$ 0.65 (4.70); III $1.65+0.95+1.20+1.20+0.80(5.80) ;$ IV
$1.50+0.80+1.25+1.40+0.80(5.75)$. Leg spination: I: Fm d 1-1-5; Pt pr and rt 1; Tb d 1-0-0, pr and rt 1-1-1ap, v 11-2 ap; Mt pr and rt 1-1 ap, v 2-2 ap. II: Fm d 1-2-5; Pt pr and rt $1 ;$ Tb d $1-0-0$, pr and rt $1-1-1$, v 1-0-2 ap; Mt pr and rt 1-1ap, v 2-2 ap. III: Fm d 1-3-5; Pt pr and rt 1; Tb d 1-0 0 , pr and rt 1-1-1-1, v 2-0-2 ap; Mt d 1-1-0, pr and rt 10-2 ap, v 1-1-2 ap. IV: Fm d 1-2-5; Pt pr and rt 1; Tb d 1$0-0$, pr 1-1-1-0, rt 1-1-1-1, v 2-0-2 ap; Mt d 1-1-0, pr 11-2 ap, rt 1-0-2 ap, v 1-1-2 ap. Coloration (in alcohol). Carapace dark brown, almost black, laterally with brownish scales, dorsally with white and yellowish scales. Pattern on thoracal part unclear because scales were partly lost (Fig. 39). Eye field at the AME area covered with white scales and with a V-shaped pattern formed by brown-yellow scales (Figs 44-45). Sternum brown, covered with white scales (Fig. 40). Labium and endites brown, pale apically. Cheeks black, covered with white hairs. Clypeus black, covered with yellow-brown long hairs, medially with a thin vertical strip of white hairs (Figs 44-45). Chelicerae dark brown, covered with dark brown hairs. Abdomen yellow-brown ventrally, covered with white scales; dorsally dark brown, almost black, covered with white scales and with a thin transverse scutum in its anterior part (Fig. 39). Book-lungs yellow-brown. Anterior spinnerets yellow, posterior dark brown. All legs brownish yellow, covered with white hairs. Coxae and trochanters yellow-brown. Tibiae, metatarsi and tarsi I ventrally dark brown (Figs 29, 40). Palp covered with white hairs. Palpal femur, patella and tibia brownish yellow, cymbium brown. Palpal structure as in Figs 27-28, 30-34: 


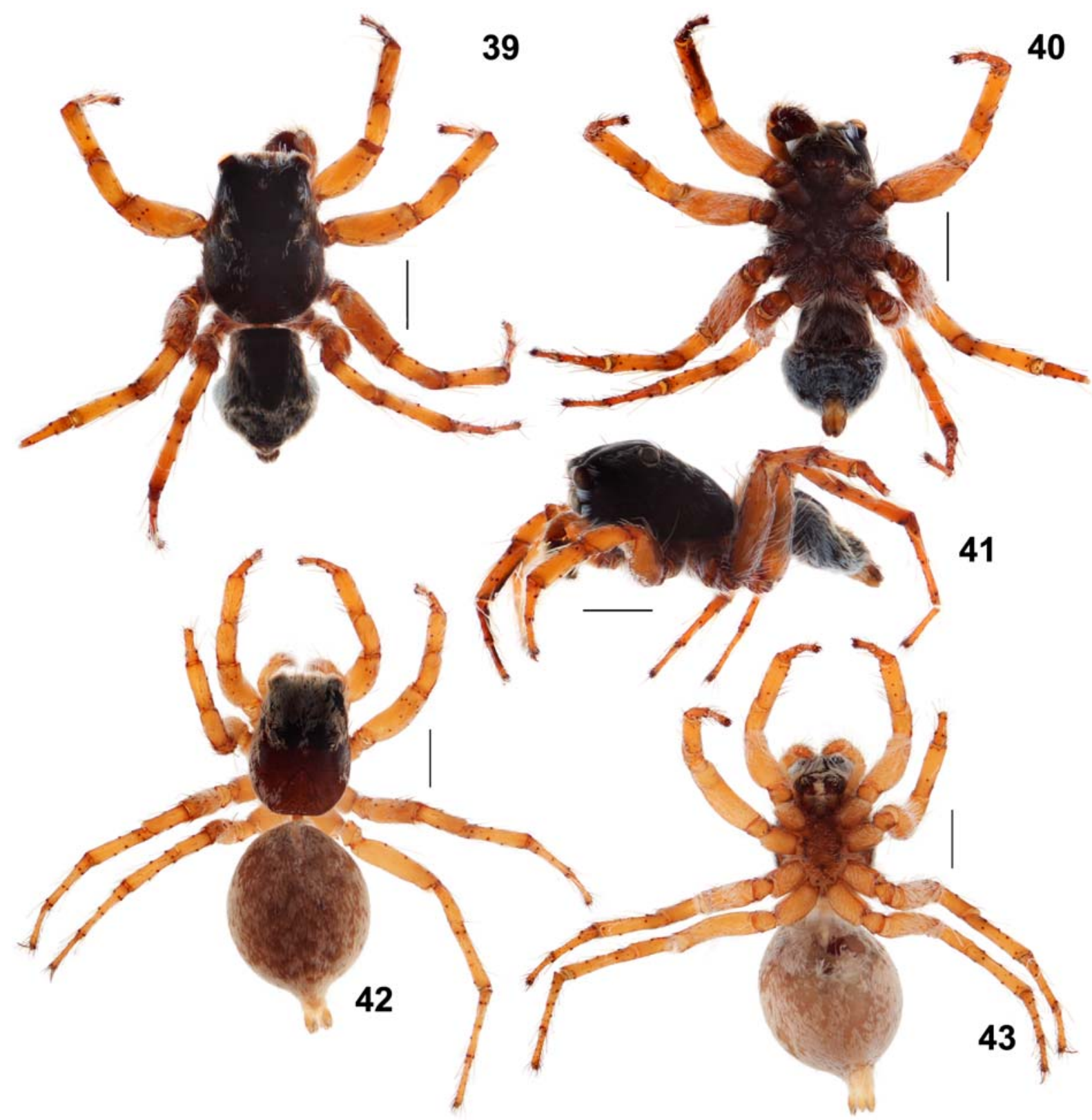

Figs 39-43. General appearance of Proszynskiana izadii sp.n.: 39 - holotype male, dorsal view; 40 - ditto, ventral view; 41 - ditto, lateral view; 42 - paratype female, dorsal view; 43 - ditto, ventral view. Scale bars $=1 \mathrm{~mm}$.

Рис. 39-43. Внешний вид Proszynskiana izadii sp.n.: 39 - голотип самец, дорсально; 40 - то же, вентрально; 41 - то же, латерально; 42 - паратип самка, дорсально; 43 — то же, вентрально. Масштаб 1 мм.

palpal tibia with three RTA - two chitinized and one membranous, the dorsal RTA poorly developed (Figs 28, 30); the embolus long and thin, bent apically, TA membranous, its outer edge poorly chitinized (Figs 31-34); SR with an apical bump (arrowed in Fig. 27).

Female (paratype): Carapace 2.60 long, 1.80 wide, 1.20 high at PLE. Ocular area 1.20 long, 1.30 wide anteriorly and 1.20 wide posteriorly. Diameter of AME 0.40. Abdomen 3.00 wide. Cheliceral length 0.60 . Clypeal height 0.20 . Length of leg segments: I $1.20+0.75+0.80+0.70+0.60(4.05)$; II $1.30+0.75+0.90+0.80+0.60(4.35) ;$ III $1.60+0.95+$ $1.10+1.30+0.65(5.60) ; \operatorname{IV} 1.60+0.80+1.20+1.25+$ 0.70 (5.55). Leg spination: I: Fm d 1-1-2; Tb pr 1-1, v 1-0-
2 ap; Mt v 2-2 ap. II: Fm d 1-2-5; Tb pr 1-1, rt 1-0, v 1-02 ap; Mt pr 1-1, and rt 1-0ap, v 2-2 ap. III: Fm d 1-2-3; Pt pr and rt 1; Tb d 1-0-0, pr and rt 1-1-1, v 1-0-2 ap; Mt d $1-1-0$, pr and rt 1-0-2 ap, v 1-1-2 ap. IV: Fm d 1-1-2; Pt pr and rt 1; Tb d 1-0-0, pr and rt 1-1-1, v 1-0-2 ap; Mt d 1-1-0, pr 1-1-2 ap, rt 1-0-2 ap, v 1-1-1-2 ap. Coloration (in alcohol). Carapace brown, with black eye field, covered with white scales. Eye field with two short longitudinal yellowish stripes connected in the AME area (Fig. 46). Scales on thoracal part almost lost, a pattern unclear (Fig. 42). Sternum yellow-brown, covered with white hairs (Fig. 43). Labium and endites yellow-brown, pale apically. Clypeus and cheeks brown, chelicerae dark brown, covered with 


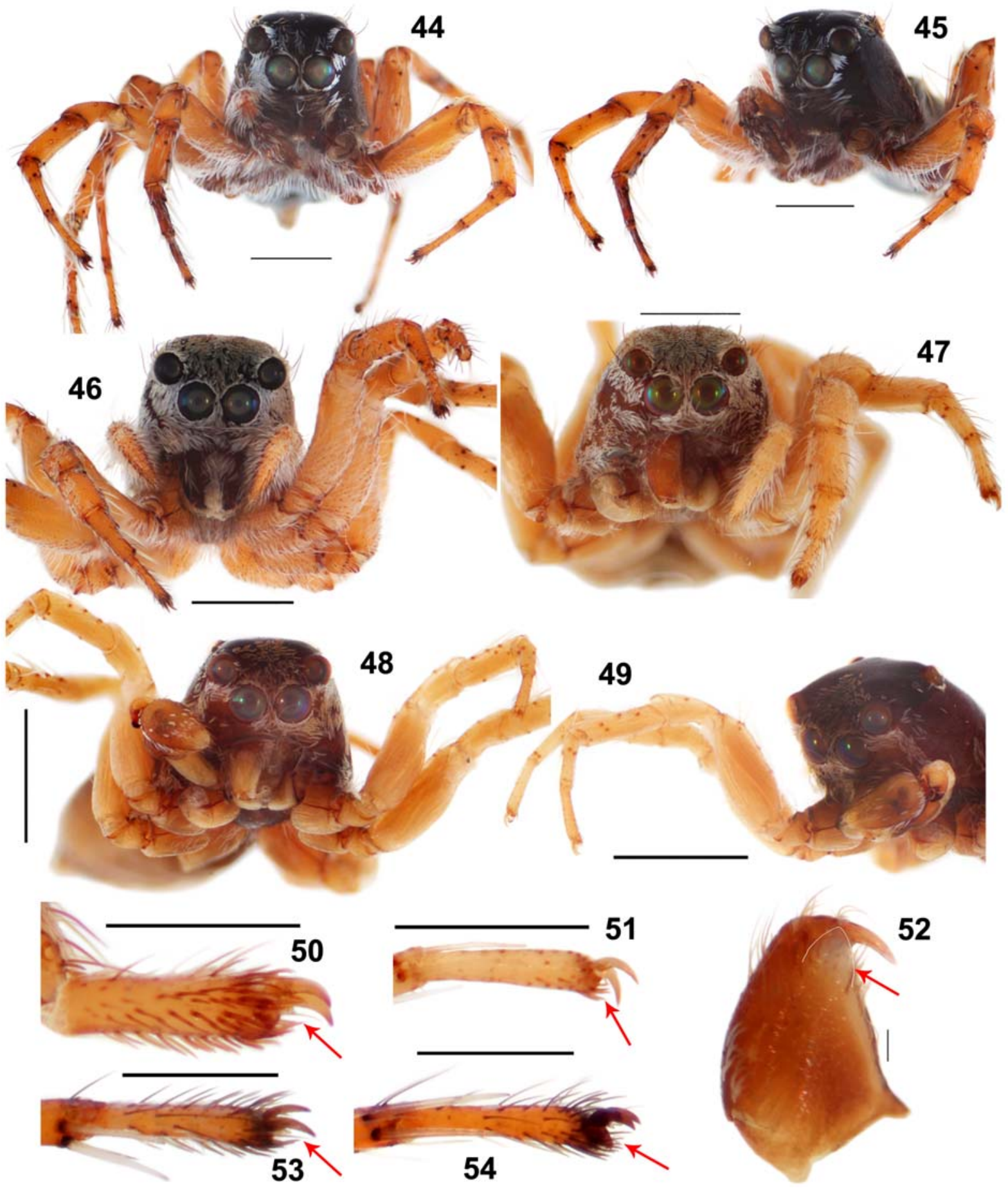

Figs 44-54. Somatic characters of Proszynskiana izadii sp.n. (44-46, 53, 54) and P. logunovi sp.n. (47-52): 44 -holotype male, frontal view; 45 - ditto, latero-frontal view; 46 - ditto, paratype female, frontal view; 47 - paratype female, frontal view; 48 - ditto, holotype-male, frontal view; 49 - ditto, latero-frontal view; 50 - female tarsus I, prolateral view; 51 - ditto, male tarsus I, prolateral view; 52 - ditto, female left chelicerae, promarginal view; 53 - male tarsus II, prolateral view; 54 - ditto, male tarsus II, prolateral view. Scale bars $=1 \mathrm{~mm}(44-49), 0.5 \mathrm{~mm}(50-51,53-54), 0.1 \mathrm{~mm}(52)$.

Рис. 44-54. Соматическеи признаки Proszynskiana izadii sp.n. (44-46, 53, 54) и P. logunovi sp.n. (47-52): 44 — голотип самещ, фронтально; 45 - то же, латеро-фронтально; 46 - то же, паратип самка, фронтально; 47 — паратип самка, фронтально; 48 - то же, голотип самец, фронтально; 49 - то же, латеро-фронтально; 50 - лапка I самки, пролатерально; 51 - то же, лапка I самца, пролатерально; 52 - то же, левая хелицера самки, промаргинально; 53 - лапка II самки, пролатерально; 54 — то же, лапка II самца, пролатерально. Масштаб 1 мм (44-49), 0,5 мм (50-51, 53-54), 0,1 мм (52). 
white hairs (Fig. 46). Abdomen grey-yellow ventrally, covered with white scales; dorsum brown, covered with transparent white scales, forming a pine-tree pattern, which is clearer in the caudal part (Fig. 42). Book-lungs grey-yellow. Anterior spinnerets yellow, posterior spinnerets brownish yellow. All legs and palps yellow, covered with white hairs. Epigyne was lost during preparation and its structure was not illustrated.

DISTRIBUTION. The type locality only (Map).

NATURAL HISTORY. The new species is one of the most abundant spiders in Lut Desert, being frequently encountered in its central areas by the second author during the Iranian Biological Expedition in November 2016 (only immature specimens were observed during that time; Figs 3538). All the observed specimens occurred on sandy dunes, even in the sites having sand surface temperatures reaching up to $78.2^{\circ} \mathrm{C}$.

\section{Proszynskiana logunovi sp.n. Figs 47-52, 55-70, Map.}

TYPES. HоLоTYPe $\sigma^{7}$ (ZISP) from Iran, Kirman [=Kerman], April 1859, Keyserling \& Bienert. PARATYPE: 1 + (ZISP), together with the holotype.

ETYMOLOGY. This species is dedicated to our colleague Dr Dmitri V. Logunov (Manchester, UK), who has been working on the Salticidae for many years and who described the genus Proszynskiana.

DIAGNOSIS. By the RTA conformation with two welldeveloped apophyses, the male of $P$. logunovi sp.n. is similar to that of $P$. deserticola Logunov, 1996, but differs from it in the presence of a well-developed ventral bump on the palpal tibia (Figs 62-63), which is absent in P. deserticola (cf. fig. 33 in Logunov [1996a]), and in the EO conformation: TA is membranous and hardly visible in $P$. logunovi sp.n. (Figs 64-67), whereas it is sclerotized in $P$. deserticola (cf. figs 34-35 in Logunov [1996a]). By the round structure in the middle of EP, the female of the new species is similar to that of $P$. iranica (cf. figs 68-69 and fig. 44 in Logunov [1996]), but differs from it in having the higher EP (Figs 68-69) as compared to P. iranica (fig. 45 in Logunov [1996a]; and in the EW conformation: convex in P. logunovi sp.n. (Fig. 68) and concave in P. iranus (fig. 44 in Logunov [1996a]).

DESCRIPTION. Male (holotype): Carapace 2.10 long, 1.45 wide, 1.20 high at PLE. Ocular area 0.90 long, 0.90 wide anteriorly and 0.90 wide posteriorly. Diameter of AME 0.35 . Abdomen 1.70 long, 1.40 wide. Cheliceral length 0.45 . Clypeal height 0.20. Length of leg segments: I $0.90+0.60+$ $0.70+0.55+0.40(3.15) ;$ II $1.00+0.60+0.65+0.50+$ 0.45 (3.20); III $1.40+0.60+0.75+0.90+$ tibia III absent (3.65); IV $1.20+0.60+0.90+0.60+0.45(3.75)$. Leg spination: I: Fm d 1-1-5; Pt pr and rt 1; Tb d 1-0-0, pr and rt 1-1-1ap, v 1-1-2 ap; Mt pr and rt 1-1 ap, v 2-2 ap. II: Fm d 1-2-5; Pt pr and rt 1; Tb d 1-0-0, pr and rt 1-1-1, v 1-0 2 ap; Mt pr and rt 1-1ap, v 2-2 ap. III: Fm d 1-3-5; Pt pr and rt 1; Tb d 1-0-0, pr and rt 1-1-1-0, v 1-0-2 ap; Mt d $1-1-0$, pr and rt $1-0-2$ ap, v 2-0-2 ap. IV: Fm d 1-2-5; Pt pr and rt 1; Tb d 1-0-0, pr and rt 1-1-1-0, v 1-0-2 ap; Mt d 1-1-0, pr 1-1-2 ap, rt 1-0-2 ap, v 1-1-2 ap. Coloration (in alcohol). Carapace brown, with dark brown eye field, medially brown. Almost all scales of carapace are lost, a colour pattern is hardly visible (Figs $49,55,57$ ). Sternum brown (Fig. 56). Labium and endites yellow-brown, pale apically. Clypeus and cheeks brown, covered with short brownish white hairs (Figs 48-49). Chelicerae yellow-brown. Abdomen yellow-brown ventrally, brown dorsally, almost without scales, a pattern is hardly visible (Figs 55, 57). Booklungs brownish. Anterior spinnerets yellow, posterior brown. All legs brownish yellow. Palpal femur, patella and tibia yellow, cymbium brown. Palpal organs as in Figs 61-67: palpal tibia with three RTA - two chitinized and one membranous, the dorsal RTA well-developed (Figs 62-63); the embolus thin, of a median length, apically with two bends directed dorsad, TA membranous, its outer edge poorly chitinized and undulated (Figs 64-67).

Female (paratype): Carapace 2.80 long, 2.10 wide, 1.35 high at PLE. Ocular area 1.05 long, 1.20 wide anteriorly and 1.20 wide posteriorly. Diameter of AME 0.45. Abdomen 2.20 wide. Cheliceral length 0.75 . Clypeal height 0.25 . Length of leg segments: I $1.30+0.90+0.75+0.50+0.40(3.85)$; II $1.30+0.85+0.80+0.60+0.60(4.15) ;$ III $1.85+1.10+$ $1.10+1.20+0.75(6.00)$; IV $2.00+0.90+1.15+1.35+$ 0.75 (6.15). Leg spination: I: Fm d 1-1-2; Tb pr 1-2, rt 0 1-0, v 1-0-2 ap; Mt pr 0-1ap, rt 1-1 ap, v 2-2 ap. II: Fm d 1-1-3; Tb pr 1-1, v 1-0-2 ap; Mt pr and rt 1-1ap, v 2-2 ap. III: Fm d 1-2-2; Pt pr and rt 1; Tb d 1-0-0, pr and rt 1-1-1, v $1-0-2$ ap; Mt d 1-1-0, pr and rt 1-0-2 ap, v 2-0-2 ap. IV: Fm d 1-1-1; Pt pr and rt 1; Tb d 1-0-0, pr and rt 1-1-1, v 1-0-2 ap; Mt d 1-1-0, pr 1-1-2 ap, rt 1-0-2 ap, v 1-1-2 ap. Coloration (in alcohol). Carapace brown, with dark brown eye field. Thorax covered with white scales, partly wiped. Eye field covered with white scales, in the middle part with two longitudinal patches of brownish scales (Figs 47, 59). Sternum brownish yellow (Fig. 60). Labium and endites brownish yellow, pale apically. Clypeus yellow-brown, cheeks brown, covered with short white hairs (Fig. 47). Chelicerae brown. Abdomen brownish yellow ventrally, yellow-brown dorsally, covered with white scales, partly destroyed in its caudal part. Posterior spinnerets absent (Fig. 60). Book-lungs yellow-brown. Anterior spinnerets yellow. All legs brownish-yellow. Structure of epigyne and spermathecae as in Figs 68-70: CO well-marked, round; EP wide and relatively high, occupying about $30 \%$ of the epigynal height, with a round bubble-shaped structure in the middle (Fig. 68); CD short, loop-curved, ID tube-shaped, widening distad and distally with well-marked accessory glands; PS convoluted, FD situated in the basal halves of receptacles (Fig. 69).

DISTRIBUTION. The type locality only (Map).

\section{A check-list of the Aelurillina of Iran}

Until recently, the information about the Iranian Aelurillina had been scattered across a number of papers. The most recent check-list of all spider families, including the Salticidae, of Iran was published online by Zamani et al. [2018a]. As the territory of Iran is one of the centres of species diversity, we have decided to compile and present an updated check-list of the Iranian Aelurillina, in which complete reference lists the taxonomic/faunistic records from Iran are presented (see WSC [2018] for full reference lists). Yet, new faunistic records are given for some species and distribution of all the listed species across provinces of Iran and worldwide is discussed; if necessary, relevant taxonomic comments are also provided. 
The Aelurillina of Iran

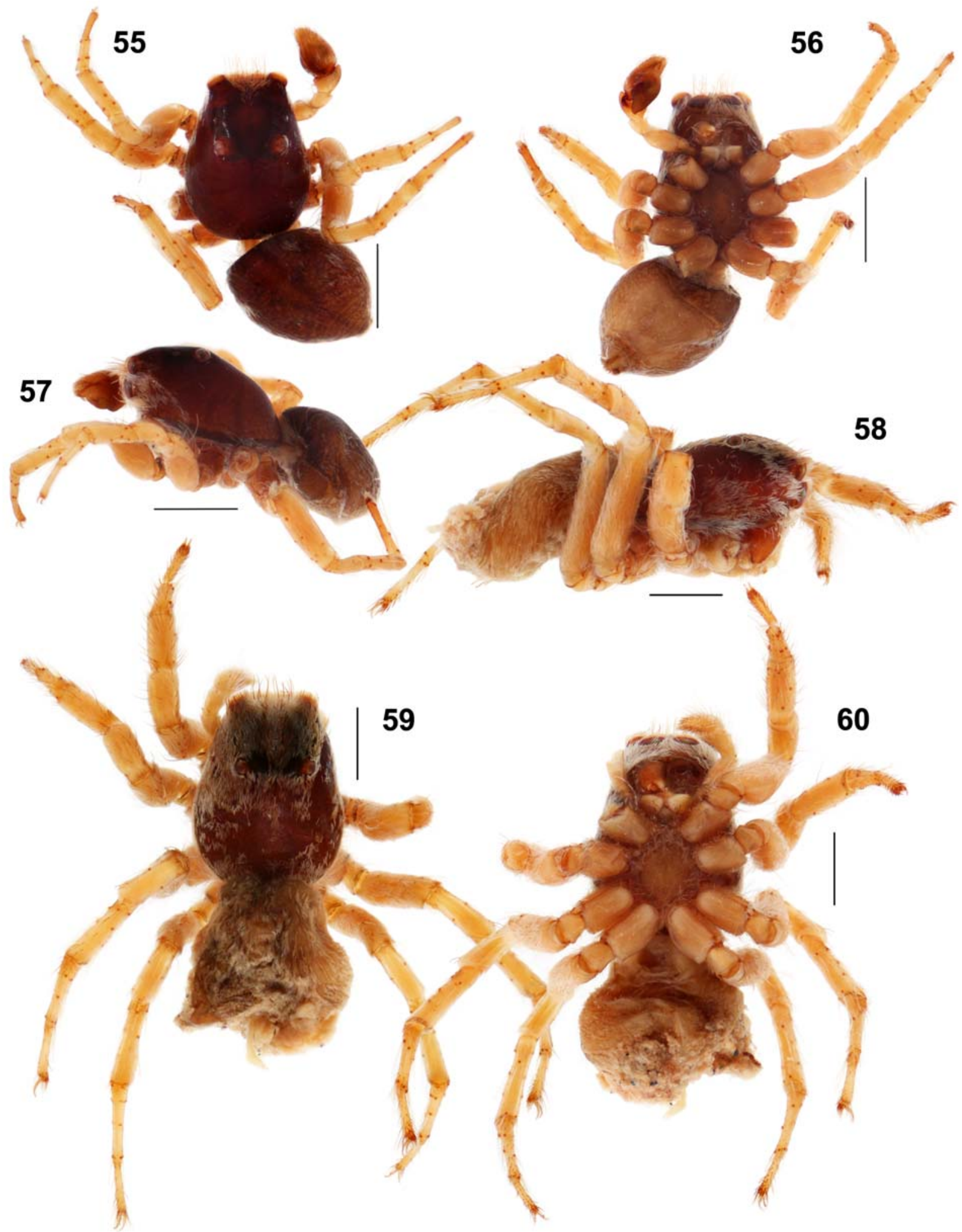

Figs 55-60. General appearance of Proszynskiana logunovi sp.n.: 55 - holotype male, dorsal view; 56 - ditto, ventral view; 57 ditto, lateral view; 58 - paratype female, dorsal view; 59 - ditto, dorsal view; 60 - ditto, lateral view. Scale bars $=1 \mathrm{~mm}$.

Рис. 55-60. Внешний вид Proszynskiana logunovi sp.n.: 55 - голотип самец, дорсально; 56 - то же, вентрально; 57 — то же, латерально; 58 - паратип самка, дорсально; 59 - то же, дорсально; 60 - то же, латерально. Масштаб 1 мм. 


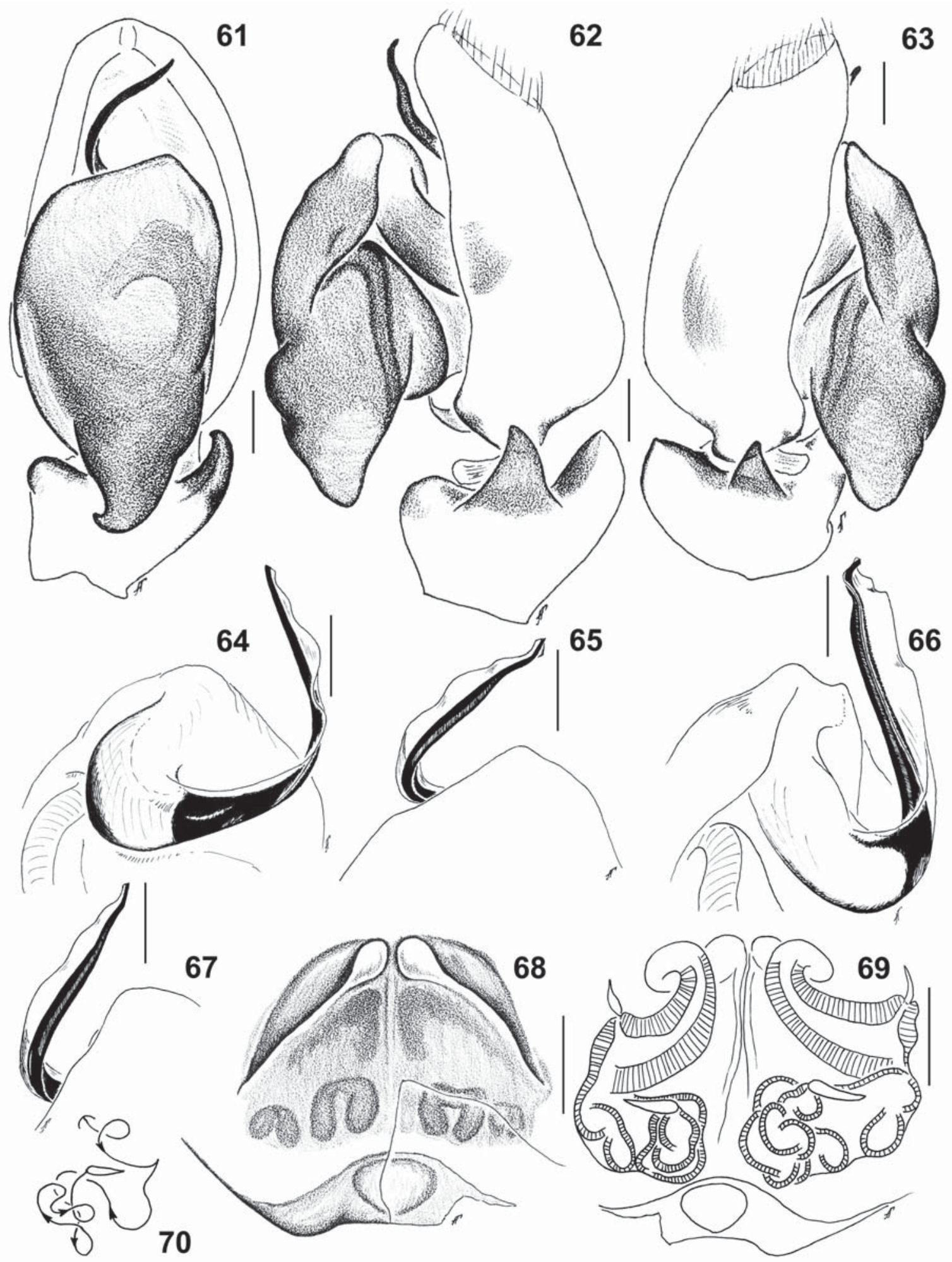

Figs 61-70. Copulatory organs of Proszynskiana logunovi sp.n.: 61 - holotype male, left palp, ventral view; 62 - ditto, retrolateral view; 63 - right palp, retrolateral view; 64 - left EO, dorsal view; 65 - ditto, ventral view; 66 — ditto, retrolateral view; 67 - ditto, prolateral view; 68 - female paratype, epigyne, ventral view; 69 - ditto, spermathecae, dorsal view; 70 - diagrammatic course of the insemination ducts. Scale bars $=0.1 \mathrm{~mm}$.

Figs 61-70. Копулятивные органы Proszynskiana logunovi sp.n.: 61 - голотип самец, левая пальпа, вентрально; 62 - то же, ретролатерально; 63 - правая пальпа, ретролатерально; 64 - ЕО левой пальпы, дорсально; 65 — то же, вентрально; 66 — то же, ретролатерально; 67 - то же, пролатерально; 68 - паратип самка, эпигина, вентрально; 69 - сперматека, дорсально; 70 - схема оплодотворительных каналов. Масштаб 0,1 мм. 
Genus Aelurillus Simon, 1884

Aelurillus concolor Kulczyński, 1901

Hemsenattus iranus Roewer, 1955: 778.

A. iranus: Prószyñski, 1966: 464-467, figs 1-4.

A. concolor: Logunov et al., 2002: 156, 164; Azarkina, Mirshamsi, 2014: 83, figs 2-33.

DISTRIBUTION. Iran (Kerman, Khuzestan, Razavi Khorasan and Tehran Provinces), from Greece to Central Asia. 2014

Aelurillus khorasanicus Azarkina et Mirshamsi,

A. khorasanicus Azarkina et Mirshamsi, 2014: 88, figs 1, 34-53. DISTRIBUTION. Iran (Razavi Khorasan Province). Endemic to Iran.

Aelurillus marusiki Azarkina, 2002

A. sp. 1.: Logunov et al., 2002: 156, 164.

A. marusiki Azarkina, 2002: 255, figs 44-53.

A. marusiki: Zamani, Mozaffarian, 2017: 15.

DISTRIBUTION. Iran (Fars, Markazi and Tehran Provinces). Endemic to Iran.

\section{Aelurillus m-nigrum Kulczyński, 1891}

A. m-nigrum: Zamani et al., 2017: 57, 65.

MATERIAL. 1 \% (MMUE, G7613.3), Isfahan Province, Qamsar and Barzok Protected Area, c. $55 \mathrm{~km} \mathrm{SW}$ of Qamsar, $14 \mathrm{~km} \mathrm{NE}$

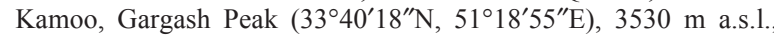
19.05.2016, P. Ponel.

DISTRIBUTION. Iran (Isfahan Province), from SouthEast Europe to China.

Aelurillus unitibialis Azarkina, 2002

A. sp. 2.: Logunov et al., 2002: 156, 164.

A. unitibialis Azarkina, 2002: 260, figs 86-95.

A. unitibialis: Zamani, Marusik, 2018: 7.

MATERIAL. 1 ऽ, 1 \% (MMUE, G7613.4), Fars Province, Sarvestan, Maharloo Lake $\left(29^{\circ} 28^{\prime} \mathrm{N}, 52^{\circ} 48^{\prime} \mathrm{E}\right), 15.08 .2016, \mathrm{M}$. Djamali; 1 \% (MMUE, G7613.5), Kerman Province: surroundings of Kal-e Shoor Lake ( $\left.31^{\circ} 00^{\prime} \mathrm{N}, 57^{\circ} 40^{\prime} \mathrm{E}\right), 290 \mathrm{~m}$ a.s.1., 12.11.2016, A. Zamani.

DISTRIBUTION. Iran (Fars and Kerman Provinces). Endemic to Iran.

Aelurillus westi sp.n.

COMMENTS. See above.

Genus Langona Simon, 1901

Langona aperta (Denis, 1958)

L. aperta: Mirshamsi et al., 2013: 118.

DISTRIBUTION. Iran (Razavi Khorasan Province), Afghanistan.

COMMENTS. It is possible that the single female of $L$. aperta recorded from Khorasan (Mashhad, $36.18^{\circ} \mathrm{N}, 59.30^{\circ} \mathrm{E}$, $980 \mathrm{~m}$ a.s.1.) by Mirshamsi et al. [2013] is conspecific with the male reported from the close locality in Khorasan under the name Langona pallidula (Torbate Haydarieh, $35.2636^{\circ} \mathrm{N}$, $59.1891^{\circ} \mathrm{E}, 1367 \mathrm{~m}$ a.s.1.) by Logunov et al. [2013]; see also comments in Logunov et al. [2013: 380]. The matter needs a special attention in the future.
Langona pallidula Logunov et Rakov, 1998

L. pallidula: Logunov et al., 2013: 380.

DISTRIBUTION. Iran (Razavi Khorasan Province), Turkmenistan.

COMMENTS. See above, under the 'Comments' for $L$. aperta.

Langona redii (Audouin, 1826)

L. redii: Logunov et al., 2002: 160, 165; Ibid., 2007: 227.

DISTRIBUTION. Iran (Khuzestan Province), Egypt, Israel, Syria, Yemen.

Langona tartarica (Charitonov, 1946) 193.

L. tartarica: Logunov et al., 2007: 227; Zamani et al., 2018b:

DISTRIBUTION. Iran (Hormozgan and Kordestan Provinces), Central Asia, Yemen, China.

Genus Phlegra Simon, 1876

Phlegra bresnieri (Lucas, 1846)

P. bresnieri: Ghahari, Marusik, 2009: 5; Ghahari, Tabari, 2012: 139; Zamani et al., 2018b: 193.

DISTRIBUTION. Iran (Isfahan, Mazandaran and Zanjan Provinces), Southern Europe, North and West Africa, Turkey, Azerbaijan.

Phlegra cinereofasciata (Simon, 1868)

P. cinereofasciata: Zamani et al., 2018b: 187.

DISTRIBUTION. Iran (Ardabil Province), from Central Europe to the eastern Caucasus.

Phlegra dunini Azarkina, 2004

P. dunini: Zamani et al., 2018b: 187.

DISTRIBUTION. Iran (Lorestan and Zanjan Provinces), Turkey, Azerbaijan.

Phlegra fasciata (Hahn, 1826)

P. fasciata: Logunov et al., 2002: 162, 165; Logunov, Koponen, 2002: 266; Kashefi et al., 2013: 13, 21; Sadeghi et al., 2016: 6 .

DISTRIBUTION. Iran (Golestan, Mazandaran, Razavi Khorasan Provinces), the temperate and subtropical regions of Eurasia.

Phlegra tetralineata (Caporiacco, 1939)

P. tetralineata: Logunov et al., 2002: 162, 165; Azarkina, 2004: 104 .

DISTRIBUTION. Iran (Tehran Province), Ethiopia.

Genus Proszynskiana Logunov, 1996

Proszynskiana izadii sp.n.

COMMENTS. See above.

Proszynskiana logunovi sp.n.

COMMENTS. See above. 
Genus Rafalus Prószyński, 1999

Rafalus variegatus (Kroneberg, 1875)

R. variegatus: Logunov et al., 2013: 380. DISTRIBUTION. Iran (Razavi Khorasan Province), Central Asia.

\section{Genus Stenaelurillus Simon, 1886}

\section{Stenaelurillus marusiki Logunov, 2001}

S. marusiki Logunov, 2001: 66, figs 27-30.

S. marusiki: Logunov et al., 2002: 163, 165.

DISTRIBUTION. Iran (Fars province). Endemic to Iran.

\section{Conclusion}

The Aelurillina fauna of Iran currently numbers 19 species in six genera, of which seven species are provisionally considered endemics of Iran. Given a high level of the regional endemism (over a third of all the recorded/described Aelurillina species), we suspect that the number of aelurillines, as well as that of the entire family Salticidae (103 species [Zamani et al., 2018a]), will increase at least one and a half to two times.

Acknowledgements. We are much obliged to D.V. Logunov (Manchester, UK) and Yu.M. Marusik (Magadan, Russia) for various inputs during the preparation of this paper. Special thanks go to D.V. Logunov for his kind linguistic help and critical comments that helped us to improve the manuscript. This work presents some results of the research project on 'Adaptation and Function of Lut Desert Biodiversity (AFLDB)' coordinated collectively by the University of Tehran, the SAEEDI Institute for Advanced Studies (SIAS) and University of Kashan (for AZ), and was partly supported by the Federal Fundamental Scientific Research Programme for 2013-2020 (No. AAAA-A16116121410121-7) (for GA).

\section{References}

Azarkina G.N. 2002. New and poorly known species of the genus Aelurillus Simon, 1884 from central Asia, Asia Minor and the eastern Mediterranean (Araneae: Salticidae) // Bulletin of the British Arachnological Society. Vol.12. Pt. 6. P.249-263.

Azarkina G.N. 2004 (for 2003). New and poorly known Palaearctic species of the genus Phlegra Simon, 1876 (Araneae, Salticidae) // Revue Arachnologique. T.14. Fasc.6. P.73-108.

Azarkina G.N., Logunov D.V. 2006. Taxonomic notes on nine Aelurillus species of the western Mediterranean (Araneae: Salticidae) // Bulletin of the British Arachnological Society. Vol.13. Pt.7. P.233-248.

Azarkina G.N., Mirshamsi O. 2014. Description of a new Aelurillus species from Khorasan province of Iran, with comments on A. concolor Kulczyński, 1901 (Araneae: Salticidae) // Zoology in the Middle East. Vol.60. No.1. P.82-91.

Azarkina G.N., Zoumides C., Hadjiconstantis M. 2018. First description of the female of Aelurillus cypriotus Azarkina 2006 (Araneae: Salticidae) // Acta Arachnologica. Vol.67. No.1. P.49-54. doi:10.2476/asjaa.67.49

Ghahari H., Marusik Y.M. 2009. New data on spider fauna of Iran (Araneae) // Turkish Journal of Arachnology. Vol.2. No.3. P.1-8.

Ghahari H., Tabari M. 2012. [Fauna and population fluctuations of spiders (Arthropoda: Araneae) in rice fields of Mazandaran
Province] // Journal of Plant Protection. Vol.26. No.2. P.136144 [in Persian].

Kashefi R., Ghassemzadeh F., Kami H.G., Mirshamsi O. 2013. New data on spider fauna from Golestan province, Iran (Arachnida, Araneae) // Progress in Biological Sciences. Vol.3. No.1. P.7-22.

Kryzhanovsky O.L. 2002. [Composition and Distribution of Entomofaunas of the Globe]. Moscow: KMK Scientific Press Ltd. 237 pp. [In Russian]

Logunov D.V. 1996a. Salticidae of Middle Asia. 3. A new genus, Proszynskiana gen. n., in the subfamily Aelurillinae (Araneae, Salticidae) // Bulletin of the British Arachnological Society. Vol.10. Pt.5. P.171-177.

Logunov D.V. 1996b. A review of the genus Phlegra Simon, 1876 in the fauna of Russia and adjacent countries (Araneae: Salticidae: Aelurillinae) // Genus. Vol.7. No.3. P.533-567.

Logunov D.V. 2001. New and poorly known species of the jumping spiders (Aranei: Salticidae) from Afghanistan, Iran and Crete // Arthropoda Selecta. Vol.10. No.1. P.59-66.

Logunov D.V. 2010. Taxonomic notes on a collection of jumping spiders from Iran (Araneae, Salticidae) // Bulletin of the British Arachnological Society. Vol.15. Pt.3. P.85-90.

Logunov D.V., Azarkina G.N. 2018. Redefinition and partial revision of the genus Stenaelurillus Simon, 1886 (Arachnida, Araneae, Salticidae) // European Journal of Taxonomy. Vol. 430. P.1-126. doi:10.5852/ejt.2018.430.

Logunov D.V., Koponen S. 2002. Redescription and distribution of Phlegra hentzi (Marx, 1890) comb. n. (Araneae, Salticidae) // Bulletin of the British Arachnological Society. Vol.12. Pt.6. P.264-267.

Logunov D.V., Marusik Yu.M., Mozaffarian F. 2002. Faunistic review of the jumping spiders of Iran (Aranei: Salticidae) // Arthropoda Selecta. Vol.10. No.2. P.155-167.

Logunov D.V., Mirshamsi O., Musavi S., Shayestehfar A. 2013. New faunistic records of Salticidae (Aranei) from Khorasan Province of Iran // Arthropoda Selecta. Vol.22. No.4. P.379381.

Logunov D. V., Vazirianzadeh B., Moravvej S.A., Navidpour S. 2007 (for 2006). New faunistic records of the jumping and crab spiders (Aranei: Salticidae, Thomisidae and Philodromidae) from Iran // Arthropoda Selecta. Vol.15. No.3. P.225-228.

Maddison W.P. 2015. A phylogenetic classification of jumping spiders (Araneae: Salticidae) // Journal of Arachnology. Vol.43. No.3. P.231-292. doi:10.1636/arac-43-03-231-292.

Mirshamsi O., Shayestehfar A., Musavi S., Hamta, A. 2013. New data on the jumping spiders from northeast of Iran (Aranei: Salticidae) // Iranian Journal of Animal Biosystematics. Vol.9. No.2. P.117-123.

Mozaffarian F., Marusik Y.M. 2001. A checklist of Iranian spiders (Aranei) // Arthropoda Selecta. Vol.10. No.1. P.67-74.

Nenilin A.B. 1984 [On the taxonomy of spiders of the family Salticidae of the fauna of the USSR and adjacent countries] // Zoologicheskii Zhurnal. Vol.43. No.8. P.1175-1180 [in Russian].

Ono H. 1988. A revisional study of the spider family Thomisidae (Arachnida, Araneae) of Japan. National Science Museum, Tokyo, ii $+252 \mathrm{pp}$.

Prószyński J. 1966. Remarks on the systematic position of Hemsenattus iranus Roewer (Arach., Araneae) // Senckenbergiana Biologica. Bd.47. H.6. P.463-467.

Roewer C.F. 1955. Die Araneen der Österreichischen Iran-Expedition 1949/50 // Sitzungsberichte der Österreichischen Akademie der Wissenschaften (I). Bd.164. H.9. S.751-782.

Sadeghi H., Ahmadi M., Zamani A., Jabaleh I. 2016. A study on the spider fauna of Dargaz and Kalat Counties in Razavi Khorasan Province, Iran (Arachnida: Araneae) // Biharean Biologist. Vol.10. No.1. P.4-7.

World Spider Catalog 2018. World Spider Catalog. Version 19.5. Natural History Museum Bern, online at http://wsc.nmbe.ch, accessed on 23.11.2018. doi: 10.24436/2.

Zamani A., Marusik Y.M. 2018. The first report on the spider fauna (Arachnida: Araneae) of the Lut Desert, Iran // Acta Arachnologica. Vol.67. No.2. P.67-75. 
Zamani A., Mirshamsi O., Dolejš P., Marusik Y.M., Esyunin S.L., Hula V., Ponel P. 2017. New data on the spider fauna of Iran (Arachnida: Araneae), Part IV // Acta Arachnologica. Vol.66. No.2. P.55-71.

Zamani A., Mozaffarian F. 2017. Further spider (Arachnida: Araneae) material deposited in the Agricultural Zoology Museum of Iran (AZMI), Iranian Research Institute of Plant Protection // Arachnologische Mitteilungen. Vol.54. P.8-20.
Zamani A., Mirshamsi O., Marusik Y.M., Moradmand M. 2018a. The Checklist of the Spiders of Iran. Version 2018, Online at http://www.spiders.ir

Zamani A., Mirshamsi O., Mohammadi Kashani G., Karami L. $2018 b$ (for 2017). New data on the spider fauna of Iran (Arachnida: Araneae), part V // Iranian Journal of Animal Biosystematics. Vol.13. No.2. P.183-197. doi:10.22067/ijab.v13i2.72404.

Responsible editor D.V. Logunov 